Jurnal Health Sains: p-ISSN: 2723-4339 e-ISSN: 2548-1398

Vol. 2, No. 8, Agustus 2021

\title{
OPTIMALISASI ALUR PELAYANAN VAKSINASI COVID-19 DI RSU X KOTA BANDUNG TAHUN 2021
}

\section{Yola Nikmatillahi, Sali Setiatin, Ihsan Marga Wiyaksa}

Politeknik Piksi Ganesha Bandung ${ }^{1,2}$, RS X Kota Bandung, Jawa Barat, Indonesia

Email: ynikmatillahi@piksi.ac.id, salisetiatin@gmail.com, ihsanmarga@gmail.com

\begin{tabular}{ll}
\hline INFO ARTIKEL & ABSTRAK \\
\hline Diterima & Angka pasien yang terinfeksi kasus positif Corona Virus Disease 2019 \\
5 Agustus 2021 & (COVID-19) di Indonesia semakin meningkat. COVID-19 sebelumnya \\
Direvisi & dikenal sebagai Novel 201 Novel Coronavirus (2019-nCoV) penyakit \\
15 Agustus 2021 & yang mengganggu sistem pernapasan. Dalam upaya menurunkan angka \\
Disetujui & kasus positif virus corona, pemerintah menghimbau seluruh masyarakat \\
25 Agustus 2021 & Indonesia untuk melakukan vaksinasi COVID-19, sebagai salah satu \\
\hline Kata Kunci: & upaya mencegah terjadinya penyebaran virus COVID-19. Pemberian \\
alur pelayanan, & vaksinasi COVID-19 dilaksanakan melalui fasilitas pelayanan kesehatan \\
vaksinasi; COVID- & pemerintah atau swasta yang telah ditunjuk dan telah memenuhi standar. \\
19; optimalisasi & Tujuan dari penelitian ini adalah menganalisa alur pelayanan vaksinasi \\
& COVID-19 di RSU X Kota Bandung. Metode penelitian yang digunakan \\
& adalah metode kualitatif dengan pendekatan deskriptif, teknik \\
& pengumpulan data menggunakan cara observasi dan studi pustaka. Hasil \\
& dari penelitian ini adalah alur pelayanan vaksinasi COVID-19 di RSU X \\
& Kota Bandung disederhanakan menjadi aturan kedua yang ditetapkan \\
& oleh Kementerian Kesehatan Republik Indonesia. Penyederhanaan alur \\
& vaksinasi COVID-19 diharapkan dapat mempermudah sasaran dan \\
& mempercepat proses pelayanan vaksinasi. Tetapi didapatkan hasil yang \\
& belum optimal dalam pemberian pelayanan vaksinasi COVID-19. \\
& Terdapat beberapa kendala seperti lamanya waktu skrining, entry data, \\
& ketentuan ruang dan waktu yang kurang efektif sehingga menimbulkan \\
& antrian penerima vaksin dan fasilitas penunjang pelayanan.
\end{tabular}

\section{ABSTRACT}

The number of patients infected with positive cases of Corona Virus Disease 2019 (COVID-19) in Indonesia is increasing. COVID-19 was previously known as Novel 201 Novel Coronavirus (2019-nCoV) a disease that affects the respiratory system. In an effort to reduce the number of positive cases of the corona virus, the government urges all Indonesians to vaccinate against COVID-19, as an effort to prevent the spread of the COVID-19 virus. The provision of COVID-19 vaccination is carried out through government or private health service facilities that have been appointed and have met the standards. The purpose of this study was to analyze the flow of COVID-19 vaccination services at RSU X Bandung City. The research method used is a qualitative method with a descriptive approach, data collection techniques using observation and literature study. The results of this study are the flow of COVID-19 vaccination services at RSU X Bandung City is simplified into the second rule set by the Ministry of Health of the Republic of Indonesia. The simplification of the COVID-19 vaccination flow is

$\begin{array}{lll}\text { How to cite: } & \text { Nikmatillahi, Y., Setiatin, S., \& Wiyaksa, I. M. (2021) Optimalisasi Alur Pelayanan Vaksinasi } \\ & \text { Covid-19 di RSU X Kota Bandung Tahun 2021. Jurnal Health Sains 2(8). } \\ & \text { https://doi.org/10.46799/jhs.v2i8.214 } & \\ \text { E-ISSN: } & 2723-6927 \\ \text { Published by: } & \text { Ridwan Institute }\end{array}$




\begin{tabular}{ll}
\hline Keywords: & expected to facilitate targets and speed up the process of vaccination \\
service flow; & services. However, the results were not optimal in providing COVID-19 \\
COVID-19 & vaccination services. There are several obstacles such as the length of \\
vaccinantion; & time for screening, data entry, ineffective space and time provisions, \\
optimalisation & causing queues for vaccine recipients and service support facilities. \\
\hline
\end{tabular}

\section{Pendahuluan}

Corona virus merupakan keluarga besar virus yang menyebabkan penyakit pada manusia dan hewan. Pada manusia biasanya menyebabkan penyakit infeksi saluran pernapasan, mulai flu biasa hingga penyakit yang serius seperti Middle East Respiratory Syndrome (MERS) dan Sindrom Pernafasan Akut Berat/ Severe Acute Respiratory Syndrome (SARS). Corona virus jenis baru yang ditemukan pada manusia sejak kejadian luar biasa muncul di Wuhan Cina, pada Desember 2019, kemudian diberi nama Severe Acute Respiratory Syndrome Coronavirus 2 (SARS-COV2), dan menyebabkan penyakit Corona virus Disease-2019 (COVID-19) (Kementerian Kesehatan Republik Indonesia, 2020).

The emergency committee telah menyatakan bahwa pentebaran COVID-19 dapat dihentikan jika dilakukan proteksi, deteksi dini, isolasi dan perawatan yang cepat agar tercipta implementasi sistem yang kuat untuk menghentikan penyebaran COVID-19 (Sun et al., 2020).

Dalam rangka percepatan penanganan COVID-19, kebijakan yang dilakukan adalah upaya untuk menghasilkan vaksin. Pendekatan vaksinasi merupakan upaya berikutnya yang aman dan efisien untuk dilak ukan. Dengan vaksinasi diharapkan dapat memutus dan meminimalisir rantai penularan COVID-19. Berdasarkan (Peraturan Presiden, 2021) tentang Pengadaan Vaksin dan Pelaksanaan Vaksinasi dalam rangka penanggulangan pandemi Corona Virus Disease 2019 (COVID-19) bahwa setiap orang yang telah ditetapkan sebagai sasaran penerima vaksin COVID-19 namun bagi yang menolaknya dapat dikenakan sanksi administratif, maka dari itu vaksin COVID-19 diwajibkan.

Vaksin merupakan agen biologis yang memiliki respon imun terhadap antigen spesifik yang berasal dari pathogen penyebab penyakit menular (Sari \& Sriwidodo, 2020).

Secara Bahasa vaksin berasal dari Bahasa inggris yaitu vaccine artinya suspense yang berasal dari bibit penyakit yang hidup tapi sudah dilemahkan (Hafidzi, 2020). Kemudian secara istilah vaksin merupakan sebuah produk biologis yang terbuat dari kuman, komponen kuman yang telah dilemahkan atau dimatikan yang berguna untuk merangsang timbulnya kekebalan spesifik secara aktif terhadap penyakit tertentu (Kristini, 2008).

Vaksinasi adalah proses di dalam tubuh, dimana seseorang menjadi kebal atau terlindungi dari suatu penyakit sehingga apabila suatu saat terpajan dengan penyakit tersebut maka tidak akan sakit atau hanya mengalami sakit ringan, biasanya dengan pemberian vaksin. Vaksin adalah produk biologi yang berisi antigen berupa mikroorganisme atau bagiannya atau zat yang dihasilkannya yang telah diolah sedemikian rupa sehingga aman, yang apabila diberikan kepada seseorang akan menimbulkan kekebalan spesifik secara aktif terhadap penyakit tertentu (Gurning et al., 2021). Vaksin bukanlah obat, vaksin mendorong pembentukan kekebalan spesifik tubuh agar terhindar dari tertular ataupun kemungkinan sakit berat. Selama belum ada obat yang defenitif untuk COVID-19, maka vaksin COVID-19 yang aman dan efektif serta perilaku 3M (memakasi masker, mencuci tangan dengan sabun dan menjaga jarak) adalah upaya perlindungan yang bisa kita lakukan agar terhindar dari penyakit COVID- 
19 (Kementerian Kesehatan Republik Indonesia, 2021).

Perlindungan hukum atas Vaksin COVID-19 sebagai sebuah KI yang merupakan olah pikir manusia menjadi hal yang patut untuk dipertimbangkan. Perlindungan hukum sebagaimana digagas Roscoe Pound yang memfungsikan hukum sebagai tool of social engineering membagi 3 (tiga) macam kepentingan, antara lain: pertama, kepentingan terhadap Negara sebagai salah satu badan yuridis sebagai kepentingan umum (public interest). Kedua, kepentingan sebagai Negara sebagai penjaga kepentingan sosial (social interest). Ketiga, kepentingan terhadap perseorangan terdiri dari pribadi (private interest) (Tanya et al., 2010).

Pelayanan vaksinasi COVID-19 harus menggunakan ruang atau tempat yang cukup luas dengan sirkulasi udara yang baik, ruang atau tempat pelayanan yang dibersihkan dengan cairan desinfektan sebelum dan sesudah pelayanan, fasilitas mencuci tangan memakai sabun dan air mengalir atau hand sanitizer, jarak aman antara meja pelayanan dengan petugas minimal 1-2 meter, ruang atau tempat pelayanan vaksinasi hanya untuk melayani orang sehat (Patrisia et al., 2020).

Tabel 1

Ketentuan Alur Vaksinasi COVID-19

\begin{tabular}{llll}
\hline \multicolumn{1}{c}{ Meja 1 } & \multicolumn{2}{c}{ Meja 2 } & \multicolumn{2}{c}{ Meja 3 } & \multicolumn{2}{c}{ Meja 4 } \\
\hline Pendaftaran & Disarankan >1 & Disarankan >1 & Pencatatan \\
Pencatatan & meja, sesuaikan & meja, sesuaikan & Petugas \\
(verifikasi data) & dengan jumlah & dengan jumlah & mempersilahkan \\
& tenaga kesehatan & tenga kesehatan & sasaran \\
& yang ada) & yang ada, didalam & menunggu 30 menit \\
& Skrining & ruangan dengan & (antisipasi apabila ada \\
& Anamnesa & tetap menerapkan & KIPI) \\
& Edukasi Vaksinasi & protokol & Sasaran diberikan \\
& COVID-19 & kesehatan) & kartu vaksinasi \\
& & Pemberian Vaksin & Edukasi pencegahan \\
& & & COVID-19 \\
\hline
\end{tabular}

Berdasarkan tabel diatas dapat diketahui bahwa alur vaksinasi COVID-19 terdapat 4 meja yaitu meja 1 untuk
Jam pelayanan tidak perlu lama dan jumlah sasaran yang dilayani dibatasi dalam satu sesi pelayanan. Untuk pelayanan vaksinasi COVID-19 di fasilitas pelayanan kesehatan lainnya seperti di Rumah Sakit atau Klinik baik milik pemerintah maupun swasta jadwal pelayanan dapat diatur dan disesuaikan dengan memperhatikan jadwal pelayanan kesehatanan lainnya. Pengaturan ruang dan alur pelayanan serta tetap memperhatikan protokol kesehatan dengan ketat.

Vaksin COVID-19 diberikan melalui suntikan intramuscular di bagian lengan kiri atas dengan dosis 0,5 $\mathrm{ml}$. Dosis yang diberikan beserta waktu pemberian harus sesuai dengan yang direkomendasikan untuk setiap jenis vaksin. Dengan Vaksin SinoVac sasaran harus mendapatkan dua dosis vaksin COVID-19 0,5 ml dengan interval pemberian antara dosis pertama dan kedua minimal 14 hari.

Berikut adalah ketentuan Alur Vaksinasi COVID-19 yang ditetapkan oleh Kementerian Kesehatan Republik Indonesia: pendaftaran sasaran vaksinasi dan pencatatan atau verifikasi data oleh petugas mobile. Meja 2 untuk melakukan skrining, anamnesa, 
edukasi dimana hal tersebut bertujuan untuk memastikan sasaran vaksinasi dalam keadaan sehat karena salah satu syarat vaksinasi yaitu sedang dalam kondisi sehat. Meja 3 dilakukan oleh petugas medis untuk memberikan vaksinasi sesuai dalam ketentuan dosis dan cara pemberiannya. Meja terakhir yaitu meja 4 dimana petugas mencatat sasaran yang sudah vaksin dan mempersilahkan sasaran duduk untuk menunggu 30 menit yang bertujuan untuk mengantisipasi adanya KIPI (Kejadian Ikutan Pasca Imunisasi yaitu setiap kondisi kesehatan atau serangan gejala yang terjadi setelah imunisasi, setelah 30 menit sasaran diberi edukasi mengenai pencegahan COVID-19 dan diperbolehkan pulang dengan membawa kartu vaksinasi yang diberikan oleh petugas.

Berdasarkan Subdit Imunisasi

Direktorat Surveilans dan Karantina Kesehatan Ditjen P2P - Kementerian Kesehatan alur pelayanan pelaksanaan vaksinasi COVID-19:

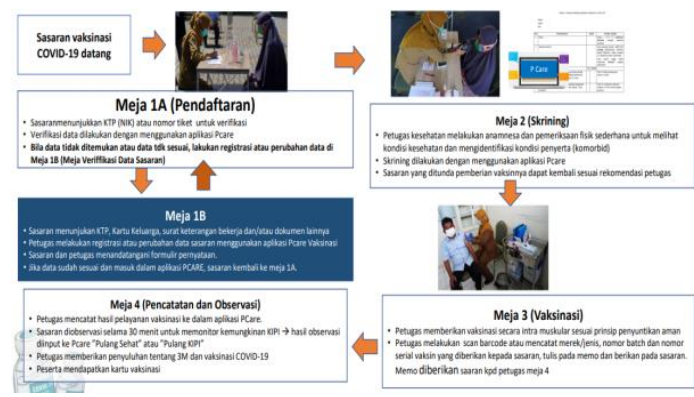

Gambar 1

Alur Pelayanan Vaksinasi COVID-19

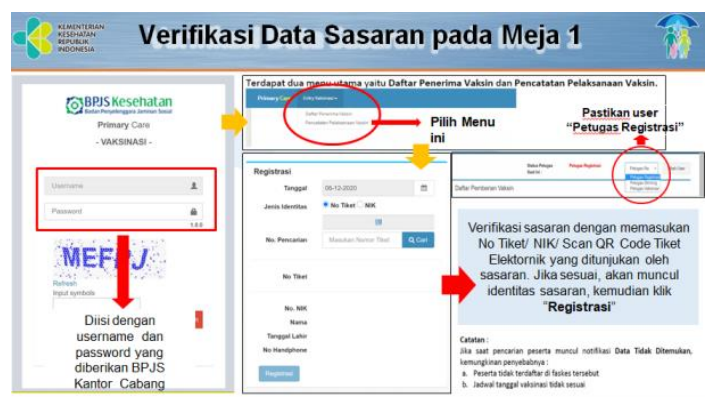

Gambar 2

Verifikasi Data Sasaran pada Meja 1

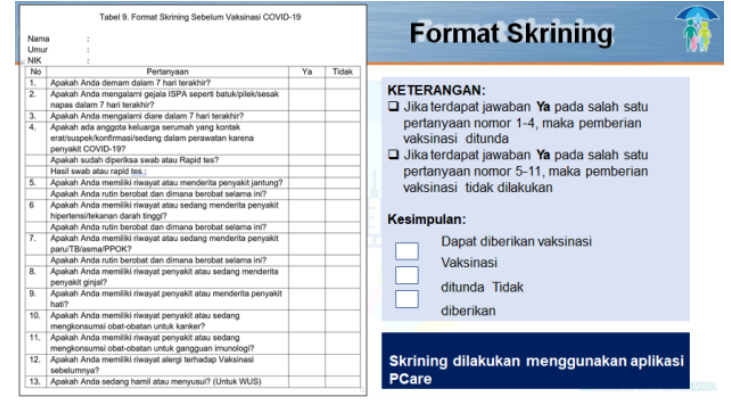

Gambar 3

Format Skrining

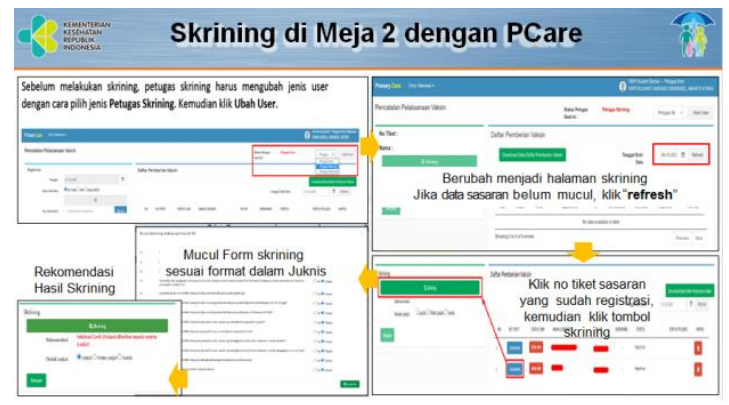

Gambar 4

Skrining di Meja 2 dengan Pcare

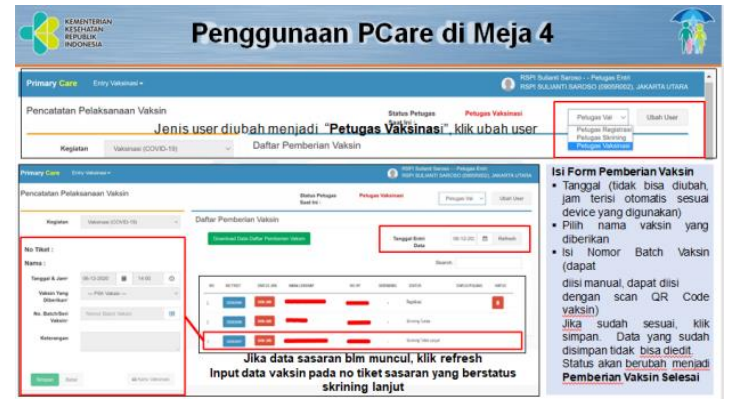

Gambar 5

Penggunaan PCare di Meja 4

Namun demikian pelaksanaan pelayanan vaksinasi COVID-19 belum sepenuhnya optimal, oleh karena itu Kementerian Kesehatan Republik Indonesia menyederhanakan alur vaksinasi COVID-19 menjadi beberapa tahap seperti gambar dibawah ini: 


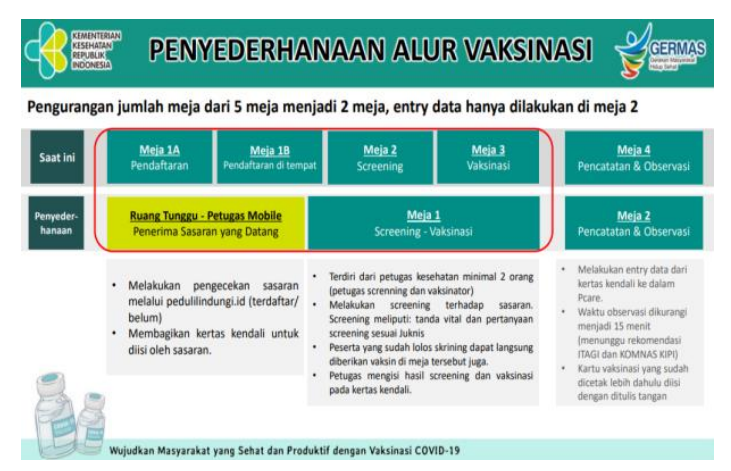

Gambar 6

\section{Penyederhanaan Alur Vaksinasi}

Gambar diatas menunjukkan bahwa alur sebelumnya terdapat 4 meja dan disederhanakan menjadi 2 meja. Meja 1A dan 1B menjadi meja ruang tunggu petugas mobile (penerima sasaran yang datang) dan Meja 2 dan 3 menjadi Meja 1 (Screening dan Vaksinasi).

\section{Metode Penelitian}

Metode yang digunakan pada penelitian ini adalah metode analisis kualitatif dengan pendekatan deskriptif. Metode kualitatif adalah sebuah metode penelitian yang secara mendalam terhadap suatu masalah daripada melihat permasalahan untuk penelitian generalisasi (M. P. P. Sugiyono \& Kuantitatif, 2012). Populasi penelitian ini meliputi Tim Vaksinasi yang telah dibentuk dari bulan Februari Tahun 2021. Lokasi penelitian ini dilakukan di salah satu rumah sakit umum di Bandung pada tanggal 05 April sampai dengan 05 Juni 2021 dengan teknik pengumpulan data berupa observasi, wawancara, dan studi pustaka.

Observasi merupakan suatu proses yang kompleks, suatu proses yang tersusun dari berbagai proses biologis dan psikologis, dua diantara yang terpenting adalah prosesproses pengamatan dan ingatan. Pada penelitian ini penulis melakukan observasi di Rumah Sakit X Kota Bandung (S. Sugiyono, 2010).

Teknik wawancara dilakukan sebagai teknik pengumpulan data untuk menemukan permasalahan yang harus diteliti, dan juga apabila ingin mengetahui hal-hal dari responden yang lebih mendalam dan jumlah respondennya sedikit/kecil.

Studi pustaka adalah teknik pengumpulan data dengan mengadakan studi penelaah terhadap buku-buku, literatur, catatan-catatan, dan laporan-laporan yang ada hubungannya dengan masalah yang dipecahkan. Teknik ini digunakan untuk memperoleh dasar-dasar dan pendapat secara tertulis yang dilakukan dengan cara mempelajari berbagai literatur yang berhubungan dengan masalah yang diteliti (Nazir et al., 2015).

Data diperoleh dari data yang relevan terhadap permasalahan yang akan diteliti dengan melakukan studi pustaka lainnya seperti buku, jurnal, artikel, peneliti terdahulu. Dalam penelitian ini penulis memperoleh data sekunder berdasarkan dari buku-buku dan juga data-data yang didapat dari instansi terkait yang berhubungan dengan penelitian.

\begin{tabular}{|c|c|c|c|}
\hline NO & PERNYATAAN & YA & TIDAK \\
\hline 1 & $\begin{array}{l}\text { Penerima vaksin duduk di } \\
\text { tempat observasi selama } 30 \\
\text { menit untuk mengantisipasi } \\
\text { adanya KIPI. }\end{array}$ & $70 \%$ & $30 \%$ \\
\hline 2 & $\begin{array}{l}\text { Jam pelayanan tidak terlalu } \\
\text { lama }\end{array}$ & $20 \%$ & $80 \%$ \\
\hline 3 & $\begin{array}{l}\text { Petugas } \\
\text { memberikan penyuluhan } \\
\text { tentang 3M (mencuci } \\
\text { tangan, memakai masker, } \\
\text { menajaga jarak) dan } \\
\text { vaksinasi COVID-19. }\end{array}$ & $50 \%$ & $50 \%$ \\
\hline 4 & $\begin{array}{l}\text { Skrining dilakukan dengan } \\
\text { menggunakan aplikasi } \\
\text { PCare. }\end{array}$ & $90 \%$ & $10 \%$ \\
\hline 5 & $\begin{array}{l}\text { Alur pelayanan sesuai } \\
\text { protokol kesehatan yang } \\
\text { ketat. }\end{array}$ & $100 \%$ & $0 \%$ \\
\hline 6 & $\begin{array}{l}\text { Pelayanan vaksinasi } \\
\text { COVID-19 menggunakan } \\
\text { ruang atau tempat yang } \\
\text { cukup luas dengan sirkulasi } \\
\text { udara yang baik. }\end{array}$ & $100 \%$ & $0 \%$ \\
\hline 7 & $\begin{array}{lrr}\text { Meja } & \text { pelayanan } & \text { antar } \\
\text { petugas } & \text { menjaga } & \text { jarak }\end{array}$ & $100 \%$ & $0 \%$ \\
\hline
\end{tabular}


Yola Nikmatillahi, Sali Setiatin, Ihsan Marga Wiyaksa

\begin{tabular}{llll}
\hline \multicolumn{5}{c}{ aman minimal 1-2 meter. } \\
\hline 8 & $\begin{array}{l}\text { Alur pelayanan vaksinasi } \\
\text { COVID-19 terdapat 4 meja } \\
\text { (pendaftaran dan } \quad \text { dan } \\
\text { pencatatan, skrining, } \\
\text { vaksinasi, serta pencatatan } \\
\text { dan observasi) }\end{array}$ \\
\hline 9 & $\begin{array}{l}\text { Terdapat fasilitas mencuci } \\
\text { tangan memakai sabun dan } \\
\text { air mengalir atau hand } \\
\text { sanitizer. }\end{array}$ \\
\hline 10 & $\begin{array}{l}\text { Ruang atau tempat } \\
\text { pelayanan vaksinasi hanya } \\
\text { untuk melayani orang sehat }\end{array}$ & \\
\end{tabular}

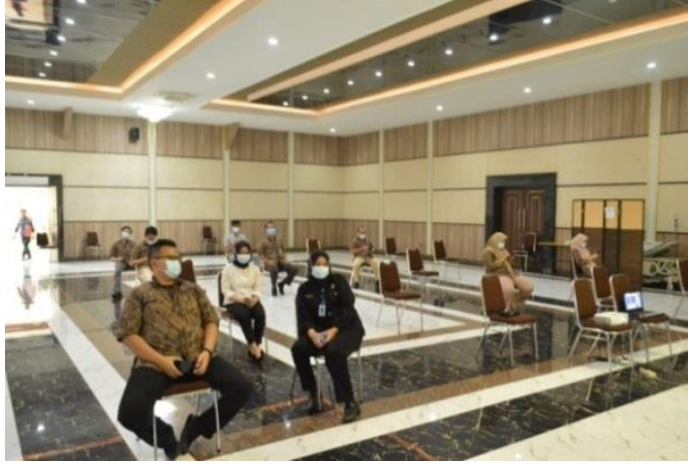

Gambar 9

Meja 2 Pencatatan dan Observasi

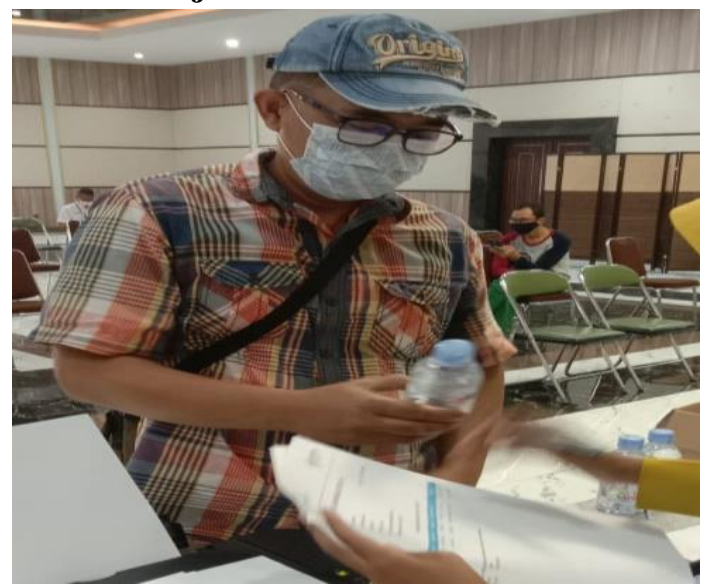

Gambar 10

Gambar 7

Meja 1 Skrining dan Vaksinasi

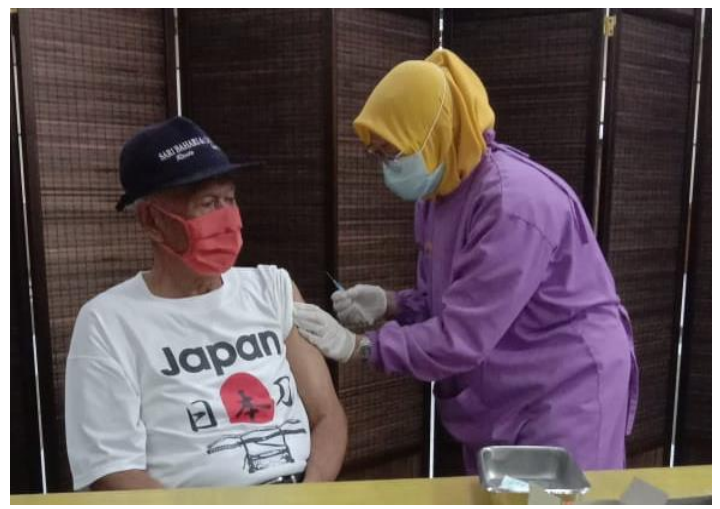

Gambar 8

Skrining dan Vaksinasi

\section{Meja 2 Pencatatan dan Observasi}

Berdasarkan hasil kuesioner terhadap beberapa responden, $70 \%$ responden menunggu selama 30 menit untuk mengantisipasi terjadinya KIPI, $30 \%$ responden tidak menunggu selama 30 menit. $20 \%$ responden menyatakan pelayanan tidak terlalu lama dan $80 \%$ responden menyatakan pelayanan terlalu lama. $50 \%$ responden menerima informasi tentang penyuluhan $3 \mathrm{M}$ dan vaksinasi COVID-19, 50\% responden tidak menerima penyuluhan tersebut. $90 \%$ responden skrining melakukan aplikasi Pcare dan $10 \%$ responden tidak di skrining oleh aplikasi Pcare. $100 \%$ responden menyatakan alur vaksinasi sesuai protocol kesehatan. $100 \%$ responden menyatakan pelayanan vaksinasi COVID-19 menggunakan ruang atau tempat yang cukup luas dengan sirkulasi udara yang baik. $100 \%$ responden menyatakan meja pelayanan antar petugas 
berjarak aman minimal 1-2 meter. $100 \%$ responden menyatakan alur pelayanan vaksinasi COVID-19 terdapat 4 meja (pendaftaran dan pencatatan, skrining, vaksinasi, serta pencatatan dan observasi). $100 \%$ responden menyatakan terdapat beberapa fasilitas mencuci tangan memakai sabun dan air mengalir atau hand sanitizer. $100 \%$ responden menyatakan ruang atau tempat pelayanan vaksinasi hanya melayani orang sehat.

Berdasarkan hasil wawancara dari Tim Vaksinasi COVID-19, vaksinasi COVID-19 di RSU X Kota Bandung telah dilakukan sejak bulan Januari tahun 2021 atas arahan langsung dari Kementerian Kesehatan Republik Indonesia melalui sistem informasi satu data. Sistem data yang terintegrasi yang digunakan untuk persiapan, pelaksanaan vaksinasi, proses pelaporan, monitoring dan evaluasi dalam penyelenggaraan vaksinasi COVID-19. Informasi tersebut disampaikan kepada petugas kesehatan dalam pelatihan imunisasi COVID-19.

Selama 5 bulan berjalan, pelayanan vaksinasi COVID-19 terdapat permasalahan dimana alur vaksinasi kurang optimal, hal tersebut terjadi karena alur pelayanan vaksinasi yang terlalu panjang. Penerima vaksin harus melewati 4 meja (meja pendaftaran, meja skrining, meja vaksinasi dan meja pendaftaran) dan waktu tunggu di meja terakhir penerima vaksin harus menunggu selama 30 menit untuk mengantisipasi apabila terdapat KIPI (Kejadian Ikutan Pasca Imunisasi) atau adanya gejala setelah menerima vaksin.

Kementerian Kesehatan Republik Indonesia mengeluarkan kebijakan baru agar alur vaksinasi COVID-19 tidak terlalu panjang dengan cara menyederhakan alur vaksinasi COVID-19 menjadi 2 meja (meja skrining - vaksinasi dan meja pencatatan observasi), dan waktu tunggu di meja observasi dipercepat menjadi 15 menit. Dengan begitu penerima vaksin tidak perlu mendaftar ulang di tempat vaksin melainkan sudah mendaftar melalui aplikasi peduli lindungi, penerima vaksin tidak perlu menunggu terlalu lama di ruang tunggu dan di meja observasi. Kebijakan tersebut sudah dilakukan uji coba terlebih dahulu di DKI Jakarta, Jawa Tengah, Sulawesi Selatan, dan Sulawesi Utara. Hal tersebut bertujuan untuk memastikan alur pelayanan vaksinasi 2 meja dapat mempermudah dan mempercepat pelayanan vaksinasi kepada sasaran.

\section{Kesimpulan}

Berdasarkan hasil pembahasan diatas, maka secara keseluruhan dapat disimpulkan bahwa optimalisasi alur pelayanan vaksinasi COVID-19 di RSU X Kota Bandung didapati beberapa kendala seperti waktu pelayanan terlalu lama dan entry data yang menggunakan waktu cukup lama. Dengan model penyederhanaan 2 meja diharapkan dapat mempermudah dan mempercepat pelayanan vaksinasi COVID-19 di RSU X Kota Bandung serta mempermudah sasaran karena meja yang harus dilalui lebih sedikit (hanya 2 meja). Namun hal tersebut ada kemungkinan penumpukan di meja 2, sehingga jumlah meja 2 sebaiknya lebih banyak dibandingkan meja 1 .

Beberapa kebutuhan logistik yang dibutuhkan pada pelayanan vaksinasi COVID-19 antara lain Handphone (untuk melakukan pengecekan di pedulilindungi.id), laptop (1-2 per tim untuk di meja 2), mesin fotokopi kertas kendali manual, printer (opsional, tidak dibutuhkan lagi apabila kartu vaksinasi sudah tersedia. Harapannya pelayananan vaksinasi COVID-19 dapat dilakukan secara optimal dengan keterbatasan sarana dan prasarana rumah sakit, agar dapat memberikan pelayanan yang paripurna dan dapat memutus rantai penyebaran virus COVID-19. 


\section{BIBLIOGRAFI}

Gurning, F. P., Siagian, L. K., Wiranti, I., Devi, S., \& Atika, W. (2021). Kebijakan Pelaksanaan Vaksinasi Covid-19 Di Kota Medan Tahun 2020. Jurnal Kesehatan, 10(1), 43-50. Google Scholar

Hafidzi, A. (2020). Kewajiban Penggunaan Vaksin: Antara Legalitas Dan Formalitas Dalam Pandangan Maqashid Al-Syariah. Yudisia: Jurnal Pemikiran Hukum Dan Hukum Islam, 11(2), 209218. Google Scholar

Kementerian Kesehatan Republik Indonesia. (2020). Pertanyaan Dan Jawaban Terkait Coronavirus Disease 2019 ( Covid-19 ). World Health Organization, 2019, 1-13. Google Scholar

Kementerian Kesehatan Republik Indonesia. (2021). Question ( Faq ) Pelaksanaan Vaksinasi Covid-. 2020, 1-16. Google Scholar

Kristini, T. D. (2008). Faktor-Faktor Risiko Kualitas Pengelolaan Vaksin Program Imunisasi Yang Buruk Di Unit Pelayanan Swasta (Studi Kasus Di Kota Semarang). Program Pasca Sarjana Universitas Diponegoro. Google Scholar

Nazir, R., Khan, M., Masab, M., Rehman, H. U., Rauf, N. U., Shahab, S., Ameer, N., Sajed, M., Ullah, M., \& Rafeeq, M. (2015). Accumulation Of Heavy Metals (Ni, Cu, Cd, Cr, Pb, Zn, Fe) In The Soil, Water And Plants And Analysis Of Physico-Chemical Parameters Of Soil And Water Collected From Tanda Dam Kohat. Journal of Pharmaceutical Sciences And Research, 7(3), 89. Google Scholar

Patrisia, I., Juhdeliena, J., Kartika, L., Pakpahan, M., Siregar, D., Biantoro, B., Hutapea, A. D., Khusniyah, Z., Sihombing, R. M., \& Mukhoirotin, M. (2020). Asuhan Keperawatan Pada
Kebutuhan Dasar Manusia. Yayasan Kita Menulis. Google Scholar

Peraturan Presiden. (2021). Peraturan Presiden Republik Indonesia Nomor 14 Tahun 2021 Tentang Perubahan Atas Peraturan Presiden Nomor 99 Tahun 2020 Tentang Pengadaan Vaksin Dan Pelaksanaan Vaksinasi Dalam Rangka Penanggulangan Pandemi Corona Virus Desease 2019 (Covid-19). 2019(039471), 13 Pages. Google Scholar

Sari, I. P., \& Sriwidodo, S. (2020). Perkembangan Teknologi Terkini Dalam Mempercepat Produksi Vaksin Covid-19. Majalah Farmasetika, 5(5), 204-217. Google Scholar

Sugiyono, M. P. P., \& Kuantitatif, P. (2012). Kualitatif, Dan R\&D, Bandung: Alfabeta. Cet. Vii. Google Scholar

Sugiyono, S. (2010). Metode Penelitian Kuantitatif Dan Kualitatif Dan $R \& D$. Alfabeta Bandung. Google Scholar

Sun, P., Lu, X., Xu, C., Sun, W., \& Pan, B. (2020). Understanding Of Covid - 19 Based On Current Evidence. Journal Of Medical Virology, 92(6), 548-551. Google Scholar

Tanya, B. L., Simanjuntak, Y. N., \& Hage, M. Y. (2010). Teori Hukum Strategi Tertib Manusia Lintas Ruang Dan Generasi. Yogyakarta: Genta Publishing. Google Scholar 
Optimalisasi Alur Pelayanan Vaksinasi Covid-19 di RSU X Kota Bandung Tahun 2021

\section{Copyright holder:}

Yola Nikmatillahi, Sali Setiatin, Ihsan Marga Wiyaksa (2021)

First publication right:

Jurnal Health Sains

This article is licensed under:

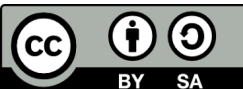

